\title{
Gestational Hypertension, Preeclampsia, and Peripartum Cardiomyopathy: A Clinical Review
}

An evidence-based guide to these major pregnancy-specific cardiovascular diseases.

By Marc-André Maheu-Cadotte, BSc, RN, Catherine Pépin, BSc, RN, Andréane Lavallée, BSc, RN, Catherine Hupé, MSN, RN, Tanya Mailhot, PhD, RN, Caroline Duchaine, BSc, RN, and Guillaume Fontaine, MSc, RN

\begin{abstract}
Gestational hypertension, preeclampsia, and peripartum cardiomyopathy are among the most common and often severe pregnancy-specific cardiovascular diseases (CVDs) and causes of complications in pregnancy. This clinical review provides nurses with an overview of pregnancyspecific CVDs, outlines their pathophysiology, and discusses risk factors and assessment. It describes management interventions according to timing: the antepartum, intrapartum, and postpartum phases are each addressed.
\end{abstract}

Keywords: breastfeeding; fetus; gestational hypertension; hypertension; preeclampsia; pregnancy complications, cardiovascular; peripartum cardiomyopathy; pregnant women; prenatal care

This is the accepted version of a published article in the American Journal of Nursing. The reference to the published article is :

Maheu-Cadotte, MA., Pepin, C., Lavallée, A., Hupé, C., Mailhot, T., Duchaine, C., et Fontaine, G. (2019). Gestational hypertension, preeclampsia, and peripartum cardiomyopathy: A clinical review of major pregnancy-specific cardiovascular diseases. American Journal of Nursing, 119(11), 32-40. doi : 10.1097/01.NAJ.0000605352.84144.a2 
Cardiovascular diseases (CVDs) constitute a leading cause of maternal and fetal mortality in pregnant women.(Umesawa et Kobashi, 2017) A large subset of these diseases is nonspecific to pregnancy (for example, ischemic and congenital heart disease, cardiac valvulopathies, and chronic hypertension) and proper management should ideally start before conception.(Adam, 2017) A smaller subset is composed of pregnancy-specific CVDs that appear only during the peripartum period. Gestational hypertension, preeclampsia, and peripartum cardiomyopathy are among the most common of these, as well as causes of complications during pregnancy.(Bello et al., 2013; Sibai, 2003; Verklan et Walden, 2015) To limit possible adverse maternal and fetal outcomes, timely recognition and management are essential.(American College of Obstetrics and Gynecologists, 2019)

In a 2018 joint statement, the World Health Organization and several other organizations asserted that all women should have access during pregnancy to a competent health care professional able to identify and manage related complications.(World Health Organization (WHO), 2018) Yet recent population studies found that inadequate peripartum follow-up — such as failure to evaluate new symptoms, revaluate existing symptoms, or respond to changes without delay-were responsible for between one-quarter and two-thirds of deaths associated with pregnancy-specific CVDs.(Hameed et al., 2015; Hernandez et al., 2018) Nurses clearly have a vital role to play in efforts aimed at the prevention, assessment, and management of pregnancy-specific CVDs.

Previous reviews targeting pregnancy-specific CVDs have been conducted mainly in the medical field, focusing on underlying risk factors and pharmacotherapy.(Anthony et al., 2016; Cairns et al., 2017; Gillon et al., 2014) One recent review published in this journal focused on the nursing approach to managing preeclampsia.(Anderson et Schmella, 2017) But to our knowledge, no review has specifically examined the role of nurses regarding pregnancy-specific CVDs in relation to maternal and fetal health.

We decided to conduct a clinical review of the literature in order to learn more. To that end, we searched the Cumulative Index of Nursing and Allied Health Literature (CINAHL), PubMed, and Google Scholar with the terms "gestational hypertension," "preeclampsia," and "peripartum cardiomyopathy" in order to find systematic reviews and primary research articles 
pertinent to our aim. We also searched for the latest clinical practice guidelines from the major national obstetrical and cardiovascular societies.

This review provides an overview of three pregnancy-specific CVDs-gestational hypertension, preeclampsia, and peripartum cardiomyopathy-and synthesizes the relevant information regarding the role of nurses in their prevention, assessment, and management.

\section{NORMAL CARDIOVASCULAR CHANGES DURING PREGNANCY}

An understanding of the normal physiological changes that occur in the maternal cardiovascular system during pregnancy allows for better comprehension of the pathophysiologic changes that occur with pregnancy-specific CVDs. This will also help nurses to distinguish between normal changes and those that may indicate a pregnancy-specific CVD.

Cardiovascular changes during pregnancy serve to ensure proper fetal blood flow. During a pregnancy, the heart will gradually be geometrically and mechanically remodeled to accommodate an increase in circulatory volume load.(Melchiorre et al., 2016) Such remodeling includes, for example, an increase in the volume and mass of the atria and ventricles. As maternal body surface area increases, cardiac output will increase significantly throughout the pregnancy.(Melchiorre et al., 2016) One study found that in singleton pregnancies, cardiac outputs increased by as much as $45 \%$ above nonpregnant levels.(Hunter et Robson, 1992) The same study also found that in twin pregnancies, the average cardiac output was $15 \%$ higher than it was in singleton pregnancies.

Although such changes are normal, tolerance for physical exertion is generally lower in pregnant than in nonpregnant women, and pregnant women may experience shortness of breath and fatigue while performing even light physical activities.(Sanghavi et Rutherford, 2014) At rest, maternal heart rate and blood pressure should remain in normal range: heart rate less than 100 beats per minute (bpm), blood pressure less than 140/90 mmHg. (It's worth noting that blood pressure often tends to drop slightly during pregnancy, most notably during the first trimester.(Cheung et Lafayette, 2013; Melchiorre et al., 2016)) In adult women, the left ventricular ejection fraction (the percentage of blood leaving the left ventricle at the end of each contraction) ranges from $54 \%$ to $74 \%$, and should not go below the lower value even in pregnancy.(Lang et al., 
2015) From the first to the third trimester, activation of the renin-angiotensin-aldosterone system causes increased retention of salt and water, which leads to a rise in blood volume, venous return, and cardiac preload.(Cheung et Lafayette, 2013) Thus edema is relatively common in pregnant women.

\section{PREVALENCE AND PATHOPHYSIOLOGY OF COMMON PREGNANCY-SPECIFIC CVDs}

Gestational hypertension is one of the most common problems in pregnant women, with prevalence ranging from $1.8 \%$ to $4.4 \%$ worldwide.(Umesawa et Kobashi, 2017) Gestational hypertension is diagnosed after 20 weeks of gestation in women with an average blood pressure of 140/90 mmHg or higher, without any of the supplementary features of preeclampsia (described below).(Butalia et al., 2018) For diagnostic purposes, blood pressure should be measured in a clinical setting twice with at least four hours between measurements, using the arm with the highest values.(Butalia et al., 2018; Pfaff, 2014) Although most women with gestational hypertension will not suffer any complications, (American College of Obstetrics and Gynecologists, 2019) the condition has been associated with higher risk for developing diabetes and kidney disease in later life.(Kintiraki et al., 2015) Gestational hypertension severity is a predictor of worse outcomes. A blood pressure higher than $160 / 110 \mathrm{mmHg}$ is considered a criterion of increased severity.(American College of Obstetrics and Gynecologists, 2019)

Preeclampsia and HELLP syndrome. Preeclampsia is another common problem, occurring in $5 \%$ to $8 \%$ of pregnant women overall and in $17 \%$ to $46 \%$ of those with gestational hypertension.(Melamed et al., 2014) Preeclampsia can be diagnosed after 20 weeks of gestation when there is new-onset hypertension with either proteinuria or indications of target organ dysfunction, including pulmonary edema; cerebrovascular disturbances (including visual disturbances like flashing lights, blurred vision); or signs of kidney failure (such as low urine output, electrolyte imbalance). Proteinuria is diagnosed when the protein-to-creatinine ratio of two urine samples taken at least six hours apart exceeds $0.3 \mathrm{mg} / \mathrm{dL}$ (American College of Obstetricians and Gynecologists, 2013; Pfaff, 2014) or when the protein concentration of a 24-hour urine excretion sample equals or exceeds $300 \mathrm{mg}$ (American College of Obstetricians and Gynecologists, 
2013; Butalia et al., 2018). If not managed, preeclampsia can progress to eclampsia, as defined by the onset of seizures. Eclampsia can be lethal; mortality rates are estimated at up to $1.8 \%$ in developed countries and up to $15 \%$ in developing countries.(Ghulmiyyah et Sibai, 2012) Although the cause of preeclampsia remains unclear, most theories cite a combination of immunologic factors and oxidative stress, leading to placental dysfunction.(Verklan et Walden, 2015) The latter leads to the release of certain antiangiogenic factors to the maternal blood flow, which cause endothelial damage and abnormal vascular remodeling.(Townsend et Drummond, 2011)

For pregnant women, preeclampsia significantly increases the risk of cardiopulmonary failure and cerebrovascular accident later in life.(Preeclampsia Foundation, 2019) It's also associated with a cluster of symptoms known as HELLP syndrome (the acronym stands for hemolysis, elevated liver enzymes, and low platelet count).(Verklan et Walden, 2015) One review found that in $70 \%$ to $80 \%$ of cases of preeclampsia, HELLP syndrome was also present.(Abildgaard et Heimdal, 2013)

Outcomes are worse in cases of early-onset or severe preeclampsia. For example, a Norwegian study found that among women with preeclampsia, the risk of stillbirth overall was about $0.5 \%$ but was substantially higher with early-onset preeclampsia.(Harmon et al., 2015)

Peripartum cardiomyopathy has been diagnosed in up to $37 \%$ of women with gestational hypertension or preeclampsia.(Bello et al., 2013) But the links between these disorders have yet to be clarified. Peripartum cardiomyopathy was once thought to be a silent underlying dilated cardiomyopathy (a condition in which the left ventricle is stretched), but it's now recognized as a distinct idiopathic cardiomyopathy that can manifest between the last month of pregnancy through the fifth month postpartum.(European Society of Gynecology (ESG) et al., 2011; Sliwa et al., 2010) Diagnosis is by exclusion: a left ventricle ejection fraction (the percentage of blood exiting with each contraction) of less than $45 \%$ has to be present on echocardiography, with this finding unexplained by another underlying heart disease.(Hibbard et al., 1999)

Multiple factors appear to be associated with peripartum cardiomyopathy, and its evolution varies among individuals.(Sharma et Kumar, 2017) The presence of certain genetic variants, excessive oxidative stress, fetal microchimerism (migration of a few fetal cells to the mother's myocardium, prompting an autoimmune response), and the abnormal metabolism of prolactin (a 
hormone involved in breast milk production) are all suggested factors in its development.(HilfikerKleiner et al., 2015; Ware et al., 2016) Many women with peripartum cardiomyopathy regain cardiac function: one study found that at one year post-delivery, $60 \%$ showed full recovery and $31 \%$ showed partial recovery.(Abou Moulig et al., 2018) Maternal and fetal outcomes are generally positive during future pregnancies.(Codsi et al., 2018) That said, about one-third of women who have had peripartum cardiomyopathy experience relapse in subsequent pregnancies.(Elkayam, 2014) At two years postpartum, maternal mortality ranges from 0\% to 9\%, with higher rates seen in women of African descent.(Sliwa et al., 2018) Outcomes are generally better when the level of maternal heart failure at time of diagnosis is classified as class I or II (little or no impact on physical activity) rather than class III or IV (marked or severe impact) per the

New York Heart Association (NYHA) Functional Classification system.(American Heart Association (AHA), 2017; Sliwa et al., 2006) For details about this system, visit http://bit.ly/30Gy1cp.

\section{RISK FACTORS AND CLINICAL ASSESSMENT}

Informing women considering pregnancy of their risk for pregnancy-specific CVDs will help them to make an informed decision. Women at higher risk include those who are older than age 30 years,(Arany, 2018) are overweight or obese,(Patel et al., 2017; Shen et al., 2017) have a preexisting metabolic or cardiovascular condition such as diabetes or hypertension,(Patel et al., 2017; Shen et al., 2017) had a previous pregnancy complicated by a pregnancy-specific CVD, or have a family history of pregnancy-specific CVDs(Sliwa et al., 2017). Furthermore, having a lower educational level is associated with higher risk for gestational hypertension and preeclampsia,(Umesawa et Kobashi, 2017) and being of African descent is associated with higher risk for peripartum cardiomyopathy.(Asad et al., 2018)

Lifestyle behaviors that promote healthy pregnancy include eating a well-balanced diet (for example, by following the dietary recommendations of the American College of Obstetricians and Gynecologists(American College of Obstetricians and Gynecologists, 2018)), engaging regularly in low- to moderate-intensity physical activity, and refraining from drinking alcohol and smoking.(Davenport et al., 2018; Gupta et Wenger, 2018) The adoption of these behaviors can help to improve metabolic outcomes and prevent other pregnancy disorders, such as gestational 
diabetes.(Gilbert et al., 2019) That said, such behavioral adoptions have not been specifically associated with reduced risks for pregnancy-specific CVDs.(Syngelaki et al., 2018) Research to develop interventions aimed at preventing pregnancy-specific CVDs is ongoing.(Ohkuchi et al., 2017)

Recognizing pregnancy-specific CVDs can often be a complex endeavor for nurses delivering peripartum care, as some of the clinical manifestations, such as dyspnea, edema, and excessive fatigue, can be confused with signs and symptoms of normal pregnancy. Noticing the onset of new signs and symptoms or the progression of existing ones are both vital to timely recognition of pregnancy-specific CVDs. For a synopsis of key diagnostic criteria for the pregnancy-specific CVDs discussed in this article, see Table 1(Abildgaard et Heimdal, 2013; Butalia et al., 2018; Hibbard et al., 1999; Pfaff, 2014; Sibai, 2003).

Gestational hypertension. Elevated blood pressure will often be the only visible sign at clinical assessment, with no further symptoms.(Surányi et al., 2017) Women with severe hypertension (160/110 $\mathrm{mmHg}$ or greater) should be admitted to a hospital for further assessment and proper management until the blood pressure falls below that threshold.(American College of Obstetrics and Gynecologists, 2019)

Preeclampsia and HELLP syndrome. Pregnant women with elevated blood pressure should also be assessed for preeclampsia, which has a different course and prognosis, and to determine whether hypertension is severe, which affects management and outcomes.(American College of Obstetrics and Gynecologists, 2019) As noted earlier, the presence of proteinuria or systemic organ dysfunction (or both) are defining features of preeclampsia. Women with elevated blood pressure should be evaluated for signs and symptoms of nervous system disorders such as hyperreflexia, clonus, tremor, headaches, paresthesia, and visual disturbances, as well as cardiovascular signs and symptoms such as oxygen saturation under 97\%. Early signs of kidney disorders are detectable by laboratory testing and include decreased glomerular filtration rate and increased urinary albumin excretion rate.(Wouters et al., 2015) Screening for proteinuria can be done at each visit using urine dipsticks.(Magee et al., 2014) Nonspecific symptoms of kidney disorders include fatigue, nausea, dyspnea, peripheral pitting edema, and oliguria.(Magee et al., 2014; Moore et al., 2018) Symptoms of liver disorders include nausea, epigastric pain at the upper 
right quadrant, and shoulder pain.(Verklan et Walden, 2015) A complete blood count and kidney and liver function tests are useful in assessing systemic organ dysfunctions.(American College of Obstetrics and Gynecologists, 2019)

Patients with HELLP syndrome often present with nonspecific symptoms that overlap with those found in preeclampsia. The cluster of symptoms seen in HELLP syndrome-hemolysis, elevated liver enzymes, and low platelet count (thrombocytopenia)-will also be present. Hemolysis is considered the "hallmark of the triad."(Sibai, 2004) Symptoms of thrombocytopenia include ecchymoses, hematuria, and bleeding from areas rich in vessels (for example, epistaxis).

Peripartum cardiomyopathy often manifests not only with physical symptoms such as dyspnea, edema, and excessive fatigue, but also with emotional symptoms such as anxiety, panic, and helplessness.(Patel et al., 2016) Delays in diagnosis can exacerbate such feelings. Early recognition is essential to ease the woman's emotional pain as well as lower the risk for further complications.

Signs and symptoms of heart failure consistent with volume overload and systemic hypoperfusion can be found in women with peripartum cardiomyopathy. Volume overload in the lungs can result in dyspnea during ordinary daily activities, orthopnea, persistent nocturnal dry cough, and paroxysmal nocturnal dyspnea.(Moioli et al., 2010) Volume overload may also lead to peripheral pitting edema.(Sharma et Kumar, 2017) Enlargement of the atria and ventricles may lead to development of ectopic foci and thus cardiac arrhythmia.(Andrade et al., 2014) At clinical assessment, cardiac auscultation may reveal new-onset murmurs, indicating a mitral or tricuspid regurgitation, and elevated jugular venous pressure.(Sharma et Kumar, 2017) Depending on the degree to which peripartum cardiomyopathy has progressed, different symptoms of heart failure at varying levels of severity may be present.(Elkayam, 2011) The patient may either have a normal heart rate or be tachycardic; and arterial hyper- or hypotension may also be found.(Elkayam, 2011) One review found that, at the time of diagnosis, about $75 \%$ of pregnant women with peripartum cardiomyopathy had heart failure symptoms corresponding to classes III or IV of the NYHA Functional Classification system.(Asad et al., 2018) That is, symptoms such as dyspnea, fatigue, and palpitations either markedly impeded daily activities (class III) or severely impeded daily activities, with discomfort even at rest (class IV).(American Heart Association (AHA), 2017) 
Fetal assessment. If the initial maternal assessment for pregnancy-specific CVDs is negative, but there are ongoing medical concerns about fetal health, fetal monitoring is recommended.(Magee et al., 2014) Performing a fetal ultrasound can permit identification of an abnormal fetal heart rate (under $120 \mathrm{bpm}$ or over $160 \mathrm{bpm}$ ), oligohydramnios (insufficient amniotic fluid), and intrauterine growth restriction (delayed fetal growth). If evidence of fetal stress is found, antenatal testing is suggested using umbilical artery Doppler velocimetry.(Kirkpatrick et al., 2017) This test examines the direction and impedance of umbilical arterial blood flow. Pregnancy-specific CVDs have been linked to placental abnormalities (such as inflammation, infarct, thrombosis), which can increase placental vascular resistance and impair blood perfusion. The absence or reversal of end-diastolic flow in the umbilical arteries can be a further indication of fetal stress.(Magee et al., 2014)

\section{MANAGEMENT}

Primary care providers should discuss with their pregnant patients the risks and benefits of pharmacotherapy for pregnancy-specific CVDs, as well as the potential impact of untreated illness, in order to determine the safest and most appropriate approach. In collaboration with other interdisciplinary team members, nurses should educate their pregnant patients about any medications that are then prescribed. Moreover, aerobic exercise is "absolutely contraindicated" in pregnant women with pregnancy-induced hypertension, preeclampsia, HELLP, and hemodynamically significant heart disease,(Kirkpatrick et al., 2017; Pfaff, 2014) and nurses should counsel patients accordingly. The timing and mode of delivery should be based on the severity of hypertension and the stability of the maternal-fetal condition.(Kirkpatrick et al., 2017) As in any pregnancy, decisions about delivery should be made collaboratively by the pregnant woman, her family members, and the health care team.

Here we address clinical management for each pregnancy-specific CVD, with consideration for when to initiate: during the antepartum, the intrapartum, or, if applicable, the postpartum phase. For a synthesis of indications for frequently used medications in these patients during pregnancy and breastfeeding, see Table 2(Alabdulrazzaq et Koren, 2012; American College of Obstetricians and Gynecologists, 2013; Bauersachs et al., 2016; Bouabdallaoui et al., 2017; 
Butalia et al., 2018; Gupta et Wenger, 2018; Magee et al., 2014; National Library of Medicine, 2018; Schlembach et al., 2015).

Gestational hypertension. Antepartum phase. First-line pharmacotherapy typically involves the administration of methyldopa (Aldomet), a centrally acting antiadrenergic, or labetalol (Trandate), a dual alpha- and nonselective beta-blocker.(Al Khaja et al., 2014) Both lower blood pressure mainly through vasodilation. Although antihypertensive medication can be initiated if the blood pressure is over $150 / 100 \mathrm{mmHg}$, for pregnant women this isn't usually recommended unless the blood pressure is consistently over 160/110 mmHg.(American College of Obstetricians and Gynecologists, 2013; Kirkpatrick et al., 2017) Prolonged or severe hypertension can lead to central nervous system injury.(Kirkpatrick et al., 2017)

Once pharmacotherapy begins, maternal blood pressure must be closely monitored to evaluate treatment effectiveness and to avoid hypoperfusion; a diastolic blood pressure of 85 mmHg should be the target.(Butalia et al., 2018) Nurses can suggest home self-monitoring with an automated blood pressure device and explain its use.(Uhlig et al., 2013) For best results, patients should refrain from exercising at least 30 minutes before taking a reading and should sit up straight with the legs uncrossed and the feet flat; the upper arm should be unclothed and held at heart level. Blood pressure should be measured at the same time daily. The correct cuff size matters - it should be 1.5 times arm circumference - and nurses or pharmacists can help women to determine the right size. Partial bed rest may be recommended for women with mild hypertension (between 140/90 and $159 / 109 \mathrm{mmHg}$ ). Strict bed rest is not advised because of the increased risk for thromboembolism.(Spiro et Scemons, 2018)

Intrapartum phase. During this phase, positioning the woman in a left lateral or sitting position may help lower cardiovascular stress by avoiding aortocaval compression and reduced venous return.(Ersbøll et al., 2016) Vaginal birth is preferred when the woman is stable and there are no obstetric indications for a cesarean.(Bouabdallaoui et al., 2017) Advantages of vaginal birth include less blood loss, better hemodynamic stability, lack of surgery-related stress and anxiety, and fewer pulmonary complications.(Ray et al., 2004)

Postpartum phase. During this phase, it's recommended that maternal blood pressure be assessed at least once at three days to 10 days postpartum.(American College of Obstetrics and 
Gynecologists, 2018) As for breastfeeding and drugs commonly used to treat either gestational hypertension or preeclampsia, there are usually no contraindications.(Magee et al., 2014) As with any new parents, nurses should provide standard information and recommendations regarding the benefits of breastfeeding, proper positioning and latching of the infant on the nipple, and common problems and ways to address them.(Folker-Maglaya et al., 2018)

Preeclampsia and HELLP syndrome. Management for preeclampsia and HELLP syndrome includes all the recommendations described above for gestational hypertension, as well as the following.

Antepartum phase. During this phase, management is focused on preventing the onset of seizures. In some cases, magnesium sulfate might be administered intravenously or intramuscularly to help prevent seizures. After such administration, it's important to monitor for signs of magnesium toxicity, which include bradycardia, bradypnea, oliguria, and altered states of consciousness (such as confusion, anxiety).(Pfaff, 2014; Witcher et al., 2015)

Intrapartum phase. In women with mild preeclampsia without signs of clinical instability or indicators for preterm delivery, full-term delivery may be considered. In women with severe preeclampsia or with signs of maternal or fetal instability, delivery is recommended as soon as the maternal condition is stabilized.(Kirkpatrick et al., 2017)

Peripartum cardiomyopathy. Antepartum phase. To our knowledge, there have been no clinical trials specifically evaluating the management of heart failure in peripartum cardiomyopathy. Thus, during the antepartum phase, standard management of heart failure is warranted. This can include the cautious administration of diuretics, beta blockers, hydralazine, nitrates, and heparin.(Jackson et al., 2018) Managing volume status is essential.(Arany, 2018) As such, salt and fluid intake restriction are necessary to prevent volume overload.(Bouabdallaoui et al., 2017) Light physical activity may still be encouraged in women with peripartum cardiomyopathy.(American College of Obstetrics and Gynecologists, 2015; Jain et al., 2016)

Women with a severely impaired ejection fraction (below 25\%) despite treatment or who are in cardiogenic shock and receiving IV positive inotropes (such as dobutamine) may require mechanical support.(Loyaga-Rendon et al., 2014) Left ventricular assist devices (a surgically implanted pump that assists the heart in pumping blood) are one such type of support. In women 
with peripartum cardiomyopathy, these devices are often installed to support those who are waiting for a heart transplant.(Loyaga-Rendon et al., 2014)

Intrapartum phase. Early delivery is not indicated as long as the maternal-fetal condition is stable.(Ersbøll et al., 2016; Regitz-Zagrosek et al., 2018; Sliwa et al., 2010) In cases of maternal instability requiring the use of inotropes or mechanical support, fetal delivery by planned cesarean may reduce the hemodynamic stress. In cases of less severe maternal instability, regional anesthesia and assisted vaginal delivery are preferred. Pain control during delivery is essential. Regional anesthesia (such as epidural analgesia or continuous spinal anesthesia) can improve cardiac loading and stabilize cardiac output by reducing preload and afterload.(Langesæter et Dyer, 2011) Anesthesia also reduces anxiety and lowers sympathetic nervous system stress, which further benefits cardiovascular function.

Administration of IV fluids in this population requires close monitoring to avoid overhydration and rapid preloading. With epidural anesthesia, some women may require IV fluids before the anesthesia is delivered.(Arendt, 2019) Although crystalloid fluids $500 \mathrm{cc}$ is a typical dose,(Lindstrom et al., 2018) the potential benefits of this practice must be weighed against the risks for volume overload, hypoperfusion, and pulmonary edema.(Caughey et al., 2018) A vasopressor agent can also be added as needed.(Arendt, 2019)

Postpartum phase. There is a lack of consensus as to whether women with peripartum cardiomyopathy can safely breastfeed. Some experts have advised against it, theorizing that prolactin production could potentially exacerbate the condition.(Hilfiker-Kleiner et al., 2017; Johnson-Coyle et al., 2012; Safirstein et al., 2012) But recent literature reviews report that, unless there are pharmacologic contraindications, women with peripartum cardiomyopathy who are clinically stable should not be discouraged from breastfeeding.(Ersbøll et al., 2016; Sharma et Kumar, 2017)

With regard to future pregnancies, the left ventricular ejection fraction should be checked before attempting to conceive. Experts agree that women with an incompletely recovered ejection fraction should refrain from becoming pregnant again.(Bozkurt et al., 2016; Hess et Weinland, 2012; Sharma et Kumar, 2017) In such cases, nurses should offer counseling on contraceptive methods to reduce the odds of unplanned pregnancy.(Sharma et Kumar, 2017) Progesterone-only 
forms of contraception are recommended, and emergency contraception should be considered if need be.(Curtis et al., 2016) Combined hormonal contraceptives are contraindicated.

Fetal considerations. Pregnancy-specific CVDs can contribute to intrauterine or neonatal mortality,(Magee et al., 2014) especially in low- and middle-income countries.(Saleem et al., 2014) Pregnancy-specific CVDs also increase the risks of undesirable outcomes such as preterm birth, low birth weight, and low APGAR scores (the acronym stands for appearance, pulse, grimace, activity, respiration).(Ersbøll et al., 2016; Magee et al., 2016) The severity of the maternal condition does not directly predict fetal and neonatal outcomes.(Kirkpatrick et al., 2017) Lower gestational age and abnormal results from more than one type of fetal monitoring may be better indicators of fetal morbidity and mortality risks.(Harmon et al., 2015; Magee et al., 2014)

The delivery care plan should be made in collaboration with the parents and should address topics such as fetal prematurity, neonatal intensive care, and maternal postpartum posttraumatic stress disorder.(Butalia et al., 2018; Magee et al., 2014) All deliveries before 34 weeks of gestation should occur only in a clinical setting with the necessary maternal and neonatal intensive care resources.(Kirkpatrick et al., 2017)

Parents of infants born prematurely or with complications are likely to experience emotional shock, self-blame, sadness, and fear.(Yang et al., 2017) For such parents, being able to participate in the care of and to interact with their baby; focusing on positive aspects and improvements; receiving information about their child's health and specific needs, as well as available resources; and receiving emotional support from nurses and other health care professionals are all vital to helping them cope. 
Table 1. Synthesis of Diagnosis Criteria for Pregnancy-Specific Cardiovascular Diseases

\begin{tabular}{|c|c|c|c|c|}
\hline & $\begin{array}{l}\text { Gestational } \\
\text { hypertension(Butalia et } \\
\text { al., 2018; Pfaff, 2014) }\end{array}$ & $\begin{array}{l}\text { Preeclampsia(Abildgaard } \\
\text { et Heimdal, 2013; Butalia } \\
\text { et al., 2018; Pfaff, 2014) }\end{array}$ & $\begin{array}{l}\text { HELLP } \\
\text { syndrome(Abildgaard et } \\
\text { Heimdal, 2013; Marchand } \\
\text { et al., 1980; Sibai, 2003) }\end{array}$ & $\begin{array}{l}\text { Peripartum } \\
\text { cardiomyopathy(Hibbard } \\
\text { et al., 1999) }\end{array}$ \\
\hline $\begin{array}{l}\text { Diagnostic } \\
\text { criteria }\end{array}$ & $\begin{array}{l}\mathrm{SBP} \geq 140 \mathrm{mmHg} \text { or } \\
\mathrm{DBP} \geq 90 \mathrm{mmHg} \text {, as } \\
\text { measured at two points in } \\
\text { time at least four hours } \\
\text { apart }\end{array}$ & $\begin{array}{l}\mathrm{SBP} \geq 140 \mathrm{mmHg} \text { or } \\
\mathrm{DBP} \geq 90 \mathrm{mmHg} \text { when } \\
\text { measured at two points in } \\
\text { time at least four hours } \\
\text { apart } \\
\text { AND } \\
\text { The protein-to-creatinine } \\
\text { ratio of two urine samples } \\
\text { exceeds } 0.3 \mathrm{mg} / \mathrm{dL} \\
\text { AND/OR } \\
\text { The protein concentration } \\
\text { of a } 24 \text {-hour urine } \\
\text { excretion sample } \geq 300 \\
\text { mg }\end{array}$ & $\begin{array}{l}\text { Hemolysis (serum } \\
\text { haptoglobin } \leq 25 \mathrm{mg} / \mathrm{dL} \text { ) } \\
\text { AND } \\
\text { Elevated liver enzymes } \\
\text { (serum LDH > } 600 \mathrm{IU} / \mathrm{L} \\
\text { OR } \\
\text { total bilirubin }>1.2 \\
\mathrm{mg} / \mathrm{dL} \text { ) } \\
\text { AND } \\
\text { Low platelet count (< } \\
100,000 \text { cells } / \mu 1)\end{array}$ & $\begin{array}{l}\mathrm{LVEF}<45 \%, \text { not } \\
\text { explained by another } \\
\text { cardiac disease }\end{array}$ \\
\hline
\end{tabular}

Note: DBP, diastolic blood pressure; HELLP, hemolysis, elevated liver enzymes, low platelet count; LDH, lactate dehydrogenase; LVEF, left ventricular ejection fraction; SBP, systolic blood pressure 


\section{Table 2. Indications for Drugs Often Used In Managing Pregnancy-specific Cardiovascular Diseases}

\begin{tabular}{|c|c|c|}
\hline Drug Class & Indications during Pregnancy & Indications regarding Breastfeeding \\
\hline $\begin{array}{l}\text { Angiotensin-converting enzyme } \\
\text { inhibitors (ACEIs) (such as } \\
\text { benazepril, fosinopril) }\end{array}$ & Not recommended.(Bouabdallaoui et al., 2017) & $\begin{array}{l}\text { Generally acceptable for use.(Magee et } \\
\text { al., 2014) But certain ACEIs (such as } \\
\text { captopril, enalapril) are } \\
\text { preferred.(Bauersachs et al., 2016) }\end{array}$ \\
\hline $\begin{array}{l}\text { Angiotensin receptor blockers } \\
\text { (such as losartan, valsartan) }\end{array}$ & Not recommended.(Bouabdallaoui et al., 2017) & $\begin{array}{l}\text { Not recommended, as profound } \\
\text { hypotension in the infant may } \\
\text { result.(Gupta et Wenger, 2018) }\end{array}$ \\
\hline $\begin{array}{l}\text { Beta-blockers (such as labetalol, } \\
\text { metoprolol, propranolol) }\end{array}$ & $\begin{array}{l}\text { Generally acceptable for use.(Bouabdallaoui et } \\
\text { al., 2017) }\end{array}$ & $\begin{array}{l}\text { Generally acceptable for use.(Magee et } \\
\text { al., 2014) }\end{array}$ \\
\hline $\begin{array}{l}\text { Calcium channel blockers (such } \\
\text { as amlodipine, nifedipine) }\end{array}$ & $\begin{array}{l}\text { Generally acceptable for use.(Alabdulrazzaq et } \\
\text { Koren, 2012) }\end{array}$ & $\begin{array}{l}\text { Generally acceptable for use.(Magee et } \\
\text { al., 2014) }\end{array}$ \\
\hline $\begin{array}{l}\text { Centrally-acting antiadrenergics } \\
\text { (such as methyldopa, clonidine) }\end{array}$ & $\begin{array}{l}\text { Generally acceptable for use.(Butalia et al., } \\
\text { 2018) }\end{array}$ & $\begin{array}{l}\text { Methyldopa is generally acceptable for } \\
\text { use.(American College of Obstetricians } \\
\text { and Gynecologists, 2013; Butalia et al., } \\
\text { 2018) Clonidine is not recommended, as } \\
\text { there are potential adverse effects for the } \\
\text { infant.(National Library of Medicine, } \\
\text { 2018) }\end{array}$ \\
\hline $\begin{array}{l}\text { Diuretics (such as furosemide, } \\
\text { hydrochlorothiazide) }\end{array}$ & $\begin{array}{l}\text { Use cautiously in order to avoid compromising } \\
\text { fetal perfusion.(Bouabdallaoui et al., 2017) }\end{array}$ & $\begin{array}{l}\text { Generally acceptable for use. May } \\
\text { decrease milk production. (Schlembach } \\
\text { et al., 2015) }\end{array}$ \\
\hline
\end{tabular}




\section{REFERENCES}

Abildgaard, U. et Heimdal, K. (2013, Feb). Pathogenesis of the syndrome of hemolysis, elevated liver enzymes, and low platelet count (HELLP): a review. Eur J Obstet Gynecol Reprod Biol, 166(2), 117-123. https://doi.org/10.1016/j.ejogrb.2012.09.026

Abou Moulig, V., Pfeffer, T., Ricke-Hoch, M., Schlothauer, S., Kasten, M., Berliner, D., Koenig, T., Schwab, J., Bauersachs, J. et Hilfiker-Kleiner, D. (2018). Five-year follow-up in patients with peripartum cardiomyopathy (PPCM) shows high and stable recovery rate and longterm use of cardiovascular medication [Abstract]. Eur J Heart Fail, (Suppl S1), 396.

Adam, K. (2017, Oct-Dec). Pregnancy in women with cardiovascular diseases. Methodist Debakey Cardiovasc J, 13(4), 209-215. https://doi.org/10.14797/mdcj-13-4-209

Al Khaja, K. A., Sequeira, R. P., Alkhaja, A. K. et Damanhori, A. H. (2014, Mar). Drug treatment of hypertension in pregnancy: a critical review of adult guideline recommendations. $J$ Hypertens, 32(3), 454-463. https://doi.org/10.1097/HJH.0000000000000069

Alabdulrazzaq, F. et Koren, G. (2012, Jul). Fetal safety of calcium channel blockers. Can Fam Physician, 58(7), 746-747.

American College of Obstetricians and Gynecologists. (2018, Feb). Nutrition during pregnancy (publication $n^{0}$ FAQ001). https://www.acog.org/-/media/For-Patients/faq001.pdf

American College of Obstetricians and Gynecologists, Task Force on Hypertension in Pregnancy. (2013). Hypertension in pregnancy. Report of the American College of Obstetricians and Gynecologists' Task Force on Hypertension in Pregnancy. https://www.acog.org/ /media/Task\%20Force\%20and\%20Work\%20Group\%20Reports/ public/HypertensioninPregnancy.pdf

American College of Obstetrics and Gynecologists. (2015, Dec). ACOG committee opinion No. 650: physical activity and exercise during pregnancy and the postpartum period. Obstet Gynecol, 126(6), e135-142. https://doi.org/10.1097/AOG.0000000000001214

American College of Obstetrics and Gynecologists. (2018, May). ACOG committee opinion No. 736: optimizing postpartum care. Obstet Gynecol, 131(5), e140-e150. https://doi.org/10.1097/AOG.0000000000002633

American College of Obstetrics and Gynecologists. (2019, Feb). ACOG committee opinion No. 767: emergent therapy for acute-onset, severe hypertension during pregnancy and the postpartum period. Obstet Gynecol, 133(2), e174-e180. https://doi.org/10.1097/AOG.0000000000003075 
American Heart Association (AHA). (2017). Classes of Heart Failure. https://www.heart.org/en/health-topics/heart-failure/what-is-heart-failure/classes-ofheart-failure

Anderson, C. M. et Schmella, M. J. (2017, Nov). Preeclampsia: current approaches to nursing $\begin{array}{lllll}\text { management. } & A m & J & \text { Nurs, }\end{array}$ https://doi.org/10.1097/01.NAJ.0000526722.26893.b5

Andrade, J., Khairy, P., Dobrev, D. et Nattel, S. (2014, Apr 25). The clinical profile and pathophysiology of atrial fibrillation: relationships among clinical features, epidemiology, and mechanisms. Circ Res, 114(9), 1453-1468. https://doi.org/10.1161/CIRCRESAHA.114.303211

Anthony, J., Damasceno, A. et Ojjii, D. (2016, Mar-Apr). Hypertensive disorders of pregnancy: what the physician needs to know. Cardiovasc $J$ Afr, 27(2), 104-110. https://doi.org/10.5830/CVJA-2016-051

Arany, Z. (2018, Jan 29). Understanding peripartum cardiomyopathy. Annu Rev Med, 69, 165176. https://doi.org/10.1146/annurev-med-041316-090545

Arendt, K. W. (2019, Jan 14). Anesthesia for labor and delivery in high-risk heart disease: general considerations. UpToDate. https://www.uptodate.com/contents/anesthesia-for-labor-anddelivery-in-high-risk-heart-disease-general-considerations

Asad, Z. U. A., Maiwand, M., Farah, F. et Dasari, T. W. (2018, May). Peripartum cardiomyopathy: a systematic review of the literature. Clin Cardiol, 41(5), 693-697. https://doi.org/10.1002/clc.22932

Bauersachs, J., Arrigo, M., Hilfiker-Kleiner, D., Veltmann, C., Coats, A. J., Crespo-Leiro, M. G., De Boer, R. A., van der Meer, P., Maack, C., Mouquet, F., Petrie, M. C., Piepoli, M. F., Regitz-Zagrosek, V., Schaufelberger, M., Seferovic, P., Tavazzi, L., Ruschitzka, F., Mebazaa, A. et Sliwa, K. (2016, Sep). Current management of patients with severe acute peripartum cardiomyopathy: practical guidance from the Heart Failure Association of the European Society of Cardiology Study Group on peripartum cardiomyopathy. Eur J Heart Fail, 18(9), 1096-1105. https://doi.org/10.1002/ejhf.586

Bello, N., Rendon, I. S. H. et Arany, Z. (2013, Oct 29). The relationship between pre-eclampsia and peripartum cardiomyopathy: a systematic review and meta-analysis. J Am Coll Cardiol, 62(18), 1715-1723. https://doi.org/10.1016/j.jacc.2013.08.717

Bouabdallaoui, N., Mouquet, F., Lebreton, G., Demondion, P., Le Jemtel, T. H. et Ennezat, P. V. (2017, Jun). Current knowledge and recent development on management of peripartum cardiomyopathy. Eur Heart J Acute Cardiovasc Care, 6(4), 359-366. https://doi.org/10.1177/2048872615612465 
Bozkurt, B., Colvin, M., Cook, J., Cooper, L. T., Deswal, A., Fonarow, G. C., Francis, G. S., Lenihan, D., Lewis, E. F., McNamara, D. M., Pahl, E., Vasan, R. S., Ramasubbu, K., Rasmusson, K., Towbin, J. A., Yancy, C., American Heart Association Committee on Heart Failure and Transplantation of the Council on Clinical Cardiology, Young, C. o. C. D. i. t., Nursing, C. o. C. a. S., Prevention, C. o. E. a. et Research, C. o. Q. o. C. a. O. (2016, Dec 6). Current Diagnostic and Treatment Strategies for Specific Dilated Cardiomyopathies: A Scientific Statement From the American Heart Association. Circulation, 134(23), e579-e646. https://doi.org/10.1161/CIR.0000000000000455

Butalia, S., Audibert, F., Cote, A. M., Firoz, T., Logan, A. G., Magee, L. A., Mundle, W., Rey, E., Rabi, D. M., Daskalopoulou, S. S., Nerenberg, K. A. et Canada, H. (2018, May). Hypertension Canada's 2018 guidelines for the management of hypertension in pregnancy. Can J Cardiol, 34(5), 526-531. https://doi.org/10.1016/j.cjca.2018.02.021

Cairns, A. E., Pealing, L., Duffy, J. M. N., Roberts, N., Tucker, K. L., Leeson, P., MacKillop, L. H. et McManus, R. J. (2017, Nov 28). Postpartum management of hypertensive disorders of pregnancy: a systematic review. BMJ Open, 7(11), e018696. https://doi.org/10.1136/bmjopen-2017-018696

Caughey, A. B., Woods, S. L., Macones, G. A., Wrench, I. J., Huang, J., Norman, M. et Gramlich, L. (2018). Guidelines for intraoperative care in cesarean delivery: enhanced recovery after surgery society recommendations (part 2). Am J Obstet Gynecol, 219(6), 533-544.

Cheung, K. L. et Lafayette, R. A. (2013, May). Renal physiology of pregnancy. Adv Chronic Kidney Dis, 20(3), 209-214. https://doi.org/10.1053/j.ackd.2013.01.012

Codsi, E., Rose, C. H. et Blauwet, L. A. (2018, Feb). Subsequent pregnancy outcomes in patients with peripartum cardiomyopathy. Obstet Gynecol, 131(2), 322-327. https://doi.org/10.1097/AOG.0000000000002439

Curtis, K. M., Tepper, N. K., Jatlaoui, T. C., Berry-Bibee, E., Horton, L. G., Zapata, L. B., Simmons, K. B., Pagano, H. P., Jamieson, D. J. et Whiteman, M. K. (2016). U.S. Medical Eligibility Criteria for Contraceptive Use, 2016. MMWR Morb Mortal Wkly Rep, 65(3), 1104.

Davenport, M. H., Ruchat, S. M., Poitras, V. J., Jaramillo Garcia, A., Gray, C. E., Barrowman, N., Skow, R. J., Meah, V. L., Riske, L., Sobierajski, F., James, M., Kathol, A. J., Nuspl, M., Marchand, A. A., Nagpal, T. S., Slater, L. G., Weeks, A., Adamo, K. B., Davies, G. A., Barakat, R. et Mottola, M. F. (2018, Nov). Prenatal exercise for the prevention of gestational diabetes mellitus and hypertensive disorders of pregnancy: a systematic review and meta-analysis. Br J Sports Med, 52(21), 1367-1375. https://doi.org/10.1136/bjsports$\underline{2018-099355}$ 
Elkayam, U. (2011, Aug 9). Clinical characteristics of peripartum cardiomyopathy in the United States: diagnosis, prognosis, and management. J Am Coll Cardiol, 58(7), 659-670. https://doi.org/10.1016/j.jacc.2011.03.047

Elkayam, U. (2014, Oct 14). Risk of subsequent pregnancy in women with a history of peripartum

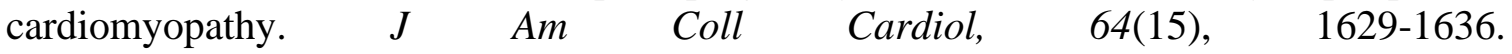
https://doi.org/10.1016/j.jacc.2014.07.961

Ersbøll, A. S., Damm, P., Gustafsson, F., Vejlstrup, N. G. et Johansen, M. (2016, Nov). Peripartum cardiomyopathy: a systematic literature review. Acta Obstet Gynecol Scand, 95(11), 12051219. https://doi.org/10.1111/aogs.13005

European Society of Gynecology (ESG), Association for European Paediatric Cardiology (AEPC), German Society for Gender Medicine (DGesGM), Regitz-Zagrosek, V., Blomstrom Lundqvist, C., Borghi, C., Cifkova, R., Ferreira, R., Foidart, J. M., Gibbs, J. S., GohlkeBaerwolf, C., Gorenek, B., Iung, B., Kirby, M., Maas, A. H., Morais, J., Nihoyannopoulos, P., Pieper, P. G., Presbitero, P., Roos-Hesselink, J. W., Schaufelberger, M., Seeland, U., Torracca, L. et Guidelines, E. C. f. P. (2011, Dec). ESC Guidelines on the management of cardiovascular diseases during pregnancy: the Task Force on the Management of Cardiovascular Diseases during Pregnancy of the European Society of Cardiology (ESC). Eur Heart J, 32(24), 3147-3197. https://doi.org/10.1093/eurheartj/ehr218

Folker-Maglaya, C., Pylman, M. E., Couch, K. A., Spatz, D. L. et Marzalik, P. R. (2018, Apr/Jun). Implementing a breastfeeding toolkit for nursing education. $J$ Perinat Neonatal Nurs, 32(2), 153-163. https://doi.org/10.1097/JPN.0000000000000330

Ghulmiyyah, L. et Sibai, B. (2012, Feb). Maternal mortality from preeclampsia/eclampsia. Semin Perinatol, 36(1), 56-59. https://doi.org/10.1053/j.semperi.2011.09.011

Gilbert, L., Gross, J., Lanzi, S., Quansah, D. Y., Puder, J. et Horsch, A. (2019, Feb 7). How diet, physical activity and psychosocial well-being interact in women with gestational diabetes mellitus: an integrative review. BMC Pregnancy Childbirth, 19(1), 60. https://doi.org/10.1186/s12884-019-2185-y

Gillon, T. E., Pels, A., von Dadelszen, P., MacDonell, K. et Magee, L. A. (2014). Hypertensive disorders of pregnancy: a systematic review of international clinical practice guidelines. PLoS One, 9(12), e113715. https://doi.org/10.1371/journal.pone.0113715

Gupta, D. et Wenger, N. K. (2018, Feb). Peripartum cardiomyopathy: status 2018. Clin Cardiol, 41(2), 217-219. https://doi.org/10.1002/clc. 22888

Hameed, A. B., Lawton, E. S., McCain, C. L., Morton, C. H., Mitchell, C., Main, E. K. et Foster, E. (2015, Sep). Pregnancy-related cardiovascular deaths in California: beyond peripartum cardiomyopathy. Am J Obstet Gynecol, 213(3), 379 e371-310. https://doi.org/10.1016/j.ajog.2015.05.008 
Harmon, Q. E., Huang, L., Umbach, D. M., Klungsøyr, K., Engel, S. M., Magnus, P., Skjærven, R., Zhang, J. et Wilcox, A. J. (2015, Mar). Risk of fetal death with preeclampsia. Obstet Gynecol, 125(3), 628-635. https://doi.org/10.1097/AOG.0000000000000696

Hernandez, L. E., Sappenfield, W. M., Harris, K., Burch, D., Hill, W. C., Clark, C. L. et Delke, I. (2018, Feb). Pregnancy-related deaths, Florida, 1999-2012: opportunities to improve maternal outcomes. Matern Child Health J, 22(2), 204-215. https://doi.org/10.1007/s10995-017-2392-y

Hess, R. F. et Weinland, J. A. (2012, Jul-Aug). The life-changing impact of peripartum cardiomyopathy: an analysis of online postings. MCN Am J Matern Child Nurs, 37(4), 241246. https://doi.org/10.1097/NMC.0b013e31824b52ed

Hibbard, J. U., Lindheimer, M. et Lang, R. M. (1999, Aug). A modified definition for peripartum cardiomyopathy and prognosis based on echocardiography. Obstet Gynecol, 94(2), 311316.

Hilfiker-Kleiner, D., Haghikia, A., Berliner, D., Vogel-Claussen, J., Schwab, J., Franke, A., Schwarzkopf, M., Ehlermann, P., Pfister, R., Michels, G., Westenfeld, R., Stangl, V., Kindermann, I., Kühl, U., Angermann, C. E., Schlitt, A., Fischer, D., Podewski, E., Böhm, M., Sliwa, K. et Bauersachs, J. (2017, Sep 14). Bromocriptine for the treatment of peripartum cardiomyopathy: a multicentre randomized study. Eur Heart J, 38(35), 26712679. https://doi.org/10.1093/eurheartj/ehx355

Hilfiker-Kleiner, D., Haghikia, A., Nonhoff, J. et Bauersachs, J. (2015, May 7). Peripartum cardiomyopathy: current management and future perspectives. Eur Heart J, 36(18), 10901097. https://doi.org/10.1093/eurheartj/ehv009

Hunter, S. et Robson, S. C. (1992, Dec). Adaptation of the maternal heart in pregnancy. Br Heart J, 68(6), 540-543. https://doi.org/10.1136/hrt.68.12.540

Jackson, A. M., Dalzell, J. R., Walker, N. L., Coats, C. J., Jhund, P. S. et Petrie, M. C. (2018, May). Peripartum cardiomyopathy: diagnosis and management. Heart, 104(9), 779-786. https://doi.org/10.1136/heartjnl-2016-310599

Jain, R., Sikerwar, V., Rajpoot, S. et Nath, K. (2016). Peripartum cardiomyopathy: A review. J Evol Med Dent Sci, 5(43), 2714-2717.

Johnson-Coyle, L., Jensen, L., Sobey, A., American College of Cardiology Foundation et Association, A. H. (2012, Mar). Peripartum cardiomyopathy: review and practice guidelines. Am J Crit Care, 21(2), 89-98. https://doi.org/10.4037/ajcc2012163

Kintiraki, E., Papakatsika, S., Kotronis, G., Goulis, D. G. et Kotsis, V. (2015, Apr-Jun). Pregnancy-Induced hypertension. Hormones (Athens), 14(2), 211-223. https://doi.org/10.14310/horm.2002.1582 
Kirkpatrick, S. J., Papile, L. A., Macones, G. A. et Practice, A. C. o. F. a. N. a. A. C. o. O. (dir.). (2017). Guidelines for perinatal care (8th ${ }^{\mathrm{e}}$ éd.). American Academy of Pediatrics and the American College of Obstetricians and Gynecologists.

Lang, R. M., Badano, L. P., Mor-Avi, V., Afilalo, J., Armstrong, A., Ernande, L., Flachskampf, F. A., Foster, E., Goldstein, S. A., Kuznetsova, T., Lancellotti, P., Muraru, D., Picard, M. H., Rietzschel, E. R., Rudski, L., Spencer, K. T., Tsang, W. et Voigt, J. U. (2015, Jan). Recommendations for cardiac chamber quantification by echocardiography in adults: an update from the American Society of Echocardiography and the European Association of Cardiovascular Imaging. $J$ Am Soc Echocardiogr, 28(1), 1-39 e14. https://doi.org/10.1016/j.echo.2014.10.003

Langesæter, E. et Dyer, R. A. (2011, Jun). Maternal haemodynamic changes during spinal anaesthesia for caesarean section. Curr Opin Anaesthesiol, 24(3), 242-248. https://doi.org/10.1097/ACO.0b013e32834588c5

Lindstrom, H., Kearney, L., Massey, D., Godsall, G. et Hogan, E. (2018). How midwives manage rapid pre-loading of fluid in women prior to low dose epidurals: A retrospective chart review. J Adv Nurs, 74(11), 2588-2595. https://doi.org/ https://doi.org/10.1111/jan.13783

Loyaga-Rendon, R. Y., Pamboukian, S. V., Tallaj, J. A., Acharya, D., Cantor, R., Starling, R. C., Naftel, D. et Kirklin, J. (2014, Mar 1). Outcomes of patients with peripartum cardiomyopathy who received mechanical circulatory support. Data from the Interagency Registry for Mechanically Assisted Circulatory Support. Circ Heart Fail, 7(2), 300-309. https://doi.org/10.1161/CIRCHEARTFAILURE.113.000721

Magee, L. A., Pels, A., Helewa, M., Rey, E., von Dadelszen, P. et Canadian Hypertensive Disorders of Pregnancy Working, G. (2014, May). Diagnosis, evaluation, and management of the hypertensive disorders of pregnancy: executive summary. J Obstet Gynaecol Can, $36(5), 416-441$.

Magee, L. A., von Dadelszen, P., Singer, J., Lee, T., Rey, E., Ross, S., Asztalos, E., Murphy, K. E., Menzies, J., Sanchez, J., Gafni, A., Helewa, M., Hutton, E., Koren, G., Lee, S. K., Logan, A. G., Ganzevoort, W., Welch, R., Thornton, J. G., Moutquin, J. M. et Group*, C. S. (2016, Nov). The CHIPS randomized controlled trial (control of hypertension in pregnancy study): is severe hypertension just an elevated blood pressure? Hypertension, 68(5), 1153-1159. https://doi.org/10.1161/HYPERTENSIONAHA.116.07862

Marchand, A., Galen, R. S. et Van Lente, F. (1980). The predictive value of serum haptoglobin in hemolytic disease. JAMA, 243(19), 1909-1911.

Melamed, N., Ray, J. G., Hladunewich, M., Cox, B. et Kingdom, J. C. (2014, Jul). Gestational hypertension and preeclampsia: are they the same disease? J Obstet Gynaecol Can, 36(7), 642-647. https://doi.org/10.1016/S1701-2163(15)30545-4 
Melchiorre, K., Sharma, R., Khalil, A. et Thilaganathan, B. (2016, Apr). Maternal cardiovascular function in normal pregnancy: evidence of maladaptation to chronic volume overload. Hypertension, 67(4), 754-762. https://doi.org/10.1161/HYPERTENSIONAHA.115.06667

Moioli, M., Valenzano Menada, M., Bentivoglio, G. et Ferrero, S. (2010, Feb). Peripartum cardiomyopathy. Arch Gynecol Obstet, 281(2), 183-188. https://doi.org/10.1007/s00404$\underline{009-1170-5}$

Moore, P. K., Hsu, R. K. et Liu, K. D. (2018). Management of acute kidney injury: core curriculum 2018. Am J Kidney Dis, 72(1), 136-148. https://doi.org/10.1053/j.ajkd.2017.11.021

National Library of Medicine. (2018). Drugs and Lactation Database (LactMed) [Internet]. Dans Clonidine. https://www.ncbi.nlm.nih.gov/books/NBK501628/

Ohkuchi, A., Hirashima, C., Takahashi, K., Suzuki, H. et Matsubara, S. (2017, Jan). Prediction and prevention of hypertensive disorders of pregnancy. Hypertens Res, 40(1), 5-14. https://doi.org/10.1038/hr.2016.107

Patel, H., Berg, M., Barasa, A., Begley, C. et Schaufelberger, M. (2016, Jan). Symptoms in women with peripartum cardiomyopathy: a mixed method study. Midwifery, 32, 14-20. https://doi.org/10.1016/j.midw.2015.10.001

Patel, P. A., Roy, A., Javid, R. et Dalton, J. A. (2017, Jul). A contemporary review of peripartum $\begin{array}{llll}\text { cardiomyopathy. } \quad \text { Clin } \quad \text { Med } & \text { (Lond), }\end{array}$ https://doi.org/10.7861/clinmedicine.17-4-316

Pfaff, N. F. (2014, Apr-Jun). The new hypertensive guidelines for pregnancy: what every nurse should know. J Perinat Neonatal Nurs, 28(2), 91-93. https://doi.org/10.1097/JPN.0000000000000028

Preeclampsia Foundation. (2019). Heart disease and stroke. https://www.preeclampsia.org/healthinformation/heart-disease-stroke

Ray, P., Murphy, G. J. et Shutt, L. E. (2004). Recognition and management of maternal cardiac disease in pregnancy. Br J Anaesth, 93(3), 428-439. https://doi.org/10.1093/bja/aeh194

Regitz-Zagrosek, V., Roos-Hesselink, J. W., Bauersachs, J., Blomström-Lundqvist, C., Cífková, R., De Bonis, M., Iung, B., Johnson, M. R., Kintscher, U., Kranke, P., Lang, I. M., Morais, J., Pieper, P. G., Presbitero, P., Price, S., Rosano, G. M. C., Seeland, U., Simoncini, T., Swan, L., Warnes, C. A. et Group, E. S. D. (2018, Sep 7). 2018 ESC guidelines for the management of cardiovascular diseases during pregnancy. Eur Heart J, 39(34), 3165-3241. https://doi.org/10.1093/eurheartj/ehy340

Safirstein, J. G., Ro, A. S., Grandhi, S., Wang, L., Fett, J. D. et Staniloae, C. (2012, Jan 12). Predictors of left ventricular recovery in a cohort of peripartum cardiomyopathy patients 
recruited via the internet. Int $J$ Cardiol, 154(1), 27-31. https://doi.org/10.1016/j.ijcard.2010.08.065

Saleem, S., McClure, E. M., Goudar, S. S., Patel, A., Esamai, F., Garces, A., Chomba, E., Althabe, F., Moore, J., Kodkany, B., Pasha, O., Belizan, J., Mayansyan, A., Derman, R. J., Hibberd, P. L., Liechty, E. A., Krebs, N. F., Hambidge, K. M., Buekens, P., Carlo, W. A., Wright, L. L., Koso-Thomas, M., Jobe, A. H., Goldenberg, R. L. et Investigators, G. N. M. N. H. R. S. (2014, Aug 1). A prospective study of maternal, fetal and neonatal deaths in low- and middle-income countries. Bull World Health Organ, 92(8), 605-612. https://doi.org/10.2471/BLT.13.127464

Sanghavi, M. et Rutherford, J. D. (2014, Sep 16). Cardiovascular physiology of pregnancy. Circulation, 130(12), 1003-1008. https://doi.org/10.1161/CIRCULATIONAHA.114.009029

Schlembach, D., Homuth, V. et Dechend, R. (2015, Aug). Treating hypertension in pregnancy. Curr Hypertens Rep, 17(8), 63. https://doi.org/10.1007/s11906-015-0572-y

Sharma, P. et Kumar, B. (2017). Peripartum cardiomyopathy: an obstetric review. Int J Reprod Contracept Obstet Gynecol, 6(2), 371-378.

Shen, M., Smith, G. N., Rodger, M., White, R. R., Walker, M. C. et Wen, S. W. (2017). Comparison of risk factors and outcomes of gestational hypertension and pre-eclampsia. PLoS One, 12(4), e0175914. https://doi.org/10.1371/journal.pone.0175914

Sibai, B. M. (2003, Jul). Diagnosis and management of gestational hypertension and preeclampsia. Obstet Gynecol, 102(1), 181-192.

Sibai, B. M. (2004). Diagnosis, controversies, and management of the syndrome of hemolysis, elevated liver enzymes, and low platelet count. Obstet Gynecol, 103(5 pt 1), 981-991. https://doi.org/10.1097/01.AOG.0000126245.35811.2a

Sliwa, K., Forster, O., Libhaber, E., Fett, J. D., Sundstrom, J. B., Hilfiker-Kleiner, D. et Ansari, A. A. (2006, Feb). Peripartum cardiomyopathy: inflammatory markers as predictors of outcome in 100 prospectively studied patients. Eur Heart J, 27(4), 441-446. https://doi.org/10.1093/eurheartj/ehi481

Sliwa, K., Hilfiker-Kleiner, D., Petrie, M. C., Mebazaa, A., Pieske, B., Buchmann, E., RegitzZagrosek, V., Schaufelberger, M., Tavazzi, L., van Veldhuisen, D. J., Watkins, H., Shah, A. J., Seferovic, P. M., Elkayam, U., Pankuweit, S., Papp, Z., Mouquet, F., McMurray, J. J. et Cardiomyopathy, H. F. A. o. t. E. S. o. C. W. G. o. P. (2010, Aug). Current state of knowledge on aetiology, diagnosis, management, and therapy of peripartum cardiomyopathy: a position statement from the Heart Failure Association of the European Society of Cardiology Working Group on Peripartum Cardiomyopathy. Eur J Heart Fail, 12(8), 767-778. https://doi.org/10.1093/eurjhf/hfq120 
Sliwa, K., Mebazaa, A., Hilfiker-Kleiner, D., Petrie, M. C., Maggioni, A. P., Laroche, C., RegitzZagrosek, V., Schaufelberger, M., Tavazzi, L., van der Meer, P., Roos-Hesselink, J. W., Seferovic, P., van Spandonck-Zwarts, K., Mbakwem, A., Böhm, M., Mouquet, F., Pieske, B., Hall, R., Ponikowski, P. et Bauersachs, J. (2017, Sep). Clinical characteristics of patients from the worldwide registry on peripartum cardiomyopathy (PPCM): EURObservational Research Programme in conjunction with the Heart Failure Association of the European Society of Cardiology Study Group on PPCM. Eur J Heart Fail, 19(9), 1131-1141. https://doi.org/10.1002/ejhf.780

Sliwa, K., Petrie, M. C., Hilfiker-Kleiner, D., Mebazaa, A., Jackson, A., Johnson, M. R., van der Meer, P., Mbakwem, A. et Bauersachs, J. (2018, Jun). Long-term prognosis, subsequent pregnancy, contraception and overall management of peripartum cardiomyopathy: practical guidance paper from the Heart Failure Association of the European Society of Cardiology Study Group on Peripartum Cardiomyopathy. Eur J Heart Fail, 20(6), 951962. https://doi.org/10.1002/ejhf.1178

Spiro, L. et Scemons, D. (2018). Management of chronic and gestational hypertension of pregnancy: a guide for primary care nurse practitioners. Open Nurs J, 12, 180-183. https://doi.org/10.2174/1874434601812010180

Surányi, A., Altorjay, Á., Kaiser, L., Nyári, T. et Németh, G. (2017, Apr). Evaluation of placental vascularization by three-dimensional ultrasound examination in second and third trimester of pregnancies complicated by chronic hypertension, gestational hypertension or preeclampsia. Pregnancy Hypertens, 8, 51-59. https://doi.org/10.1016/j.preghy.2017.03.004

Syngelaki, A., Sequeira Campos, M., Roberge, S., Andrade, W. et Nicolaides, K. H. (2018, Sep 6). Diet and exercise for preeclampsia prevention in overweight and obese pregnant women: systematic review and meta-analysis. J Matern Fetal Neonatal Med, 1-7. https://doi.org/10.1080/14767058.2018.1481037

Townsend, N. S. et Drummond, S. B. (2011, Jul-Sep). Preeclampsia: pathophysiology and implications for care. J Perinat Neonatal Nurs, 25(3), 245-252. https://doi.org/10.1097/JPN.0b013e318223ad14

Uhlig, K., Patel, K., Ip, S., Kitsios, G. D. et Balk, E. M. (2013, Aug 6). Self-measured blood pressure monitoring in the management of hypertension: a systematic review and metaanalysis. Ann Intern Med, 159(3), 185-194. https://doi.org/10.7326/0003-4819-159-3201308060-00008

Umesawa, M. et Kobashi, G. (2017, Mar). Epidemiology of hypertensive disorders in pregnancy: prevalence, risk factors, predictors and prognosis. Hypertens Res, 40(3), 213-220. https://doi.org/10.1038/hr.2016.126

Verklan, M. T. et Walden, M. (dir.). (2015). Core curriculum for neonatal intensive care nursing (5the éd.). Elsevier Saunders. 
Ware, J. S., Li, J., Mazaika, E., Yasso, C. M., DeSouza, T., Cappola, T. P., Tsai, E. J., HilfikerKleiner, D., Kamiya, C. A., Mazzarotto, F., Cook, S. A., Halder, I., Prasad, S. K., Pisarcik, J., Hanley-Yanez, K., Alharethi, R., Damp, J., Hsich, E., Elkayam, U., Sheppard, R., Kealey, A., Alexis, J., Ramani, G., Safirstein, J., Boehmer, J., Pauly, D. F., Wittstein, I. S., Thohan, V., Zucker, M. J., Liu, P., Gorcsan, J., 3rd, McNamara, D. M., Seidman, C. E., Seidman, J. G., Arany, Z. et Investigators, I.-a. I. (2016, Jan 21). Shared genetic predisposition in peripartum and dilated cardiomyopathies. N Engl J Med, 374(3), 233241. https://doi.org/10.1056/NEJMoa1505517

Witcher, P. M., Chez, B. F. et Baird, S. M. (2015, Jul-Sep). Multisystem effects of hypertensive disorders of pregnancy: a comprehensive review. J Perinat Neonatal Nurs, 29(3), 229-239. https://doi.org/10.1097/JPN.0000000000000114

World Health Organization (WHO), t. U. N. P. F. U., the United Nations Children's Fund (UNICEF), the International Confederation of Midwives (ICM), the International Council of Nurses (ICN), the International Federation of Gynecology and Obstetrics (FIGO) and the International Pediatric Association (IPA). (2018). Definition of skilled health personnel providing care during childbirth: the 2018 joint statement by WHO, UNFPA, UNICEF, ICM, ICN, FIGO and IPA (publication $\mathrm{n}^{\circ} \mathrm{WHO} / \mathrm{RHR} / 18.14$ ).

Wouters, O. J., O'Donoghue, D. J., Ritchie, J., Kanavos, P. G. et Narva, A. S. (2015, Aug). Early chronic kidney disease: diagnosis, management and models of care. Nat Rev Nephrol, 11(8), 491-502. https://doi.org/10.1038/nrneph.2015.85

Yang, Y. Y., He, H. G., Lee, S. Y., Holroyd, E., Shorey, S. et Koh, S. S. L. (2017, Jul/Sep). Perceptions of parents with preterm infants hospitalized in Singaporean neonatal intensive care unit. J Perinat Neonatal Nurs, 31(3), 263-273. https://doi.org/10.1097/JPN.0000000000000239 